\title{
Tissue Expression of HSP27 in Prostate Cancer Is Correlated with the Aggressivity of Cancer in the Algerien Population
}

Type of article: Conference abstract

Asma Bourefis1, Hajira Berredjem1, Omar Djeffal2 and Palma Rocchi3

1Université Badji Mokhtar-Annaba, Faculté des Sciences, Département de Biochimie, Laboratoire de Biochimie et de MicrobiologieAppliquées, Algerie

2Cabinet Médicald'Uro-Chirurgie- Annaba, Algerie

3Centre de Recherche en Cancérologie de Marseille, Inserm, Institut Pauoli-Calmettes et Aix

Marseille

Université Marseille, France

asma_bourefis@yahoo.com

\begin{abstract}
:
Prostate cancer $(\mathrm{CaP})$ is the second most common cancer in men and a major public health problem. Clinical outcomes at diagnosis are heterogeneous and difficult to predict, so predictive and diagnostic markers are needed. Heat shock proteins (Hsps) such as Hsp27 are highly regulated in several malignant tumors. Basal Hsp27 levels in most human tissues are low compared to high levels in tumors.

Objective: In this work, we evaluated, in subjects with $\mathrm{CaP}$, the levels of expression of the Hsp27 antigen in tumor tissues and its association with tumor aggressiveness.

Material and methods: The Immuno-Histo-Chimical (IHC) method was used to determine the expression of Hsp27 in 58 prostate cancer tissues and 4 prostate hyperplasia (BPH).

Results: Tissue levels of Hsp27 were significantly higher in patients with $\mathrm{CaP}$ than in BPH $(\mathrm{QSM}=$ $153.43 \pm 0 ; \mathrm{P}<0.0001)$. In the case of aggressive cancer (Gleason score $>7$ ), we found a very significant increase in Hsp27 protein (QSM $=169.73 \pm 84.26$; $\mathrm{P}<0.0001)$ compared to non-aggressive cancer (Gleason score $\leq 7)(\mathrm{QSM}=123.92 \pm 91.36$; $\mathrm{P}<0.001)$.

Conclusion: Overexpression of hsp27 in the tissues of patients with $\mathrm{CaP}$ compared to patients with $\mathrm{BPH}$ may be of diagnostic and/or prognostic interest and may be a therapeutic target in patients with prostate cancer.
\end{abstract}

Keyword: Prostate cancer, hsp27, IHC, Aggressive cancer

\section{Conflict of interest statement}

This article is a conference abstract presented at the International Congress on Health Sciences and Medical Technologies, Tlemcen Algeria 5-7 December 2019, ICHSMT'19.

\section{Authors' biography}

No Biography.

\section{References}

No references 